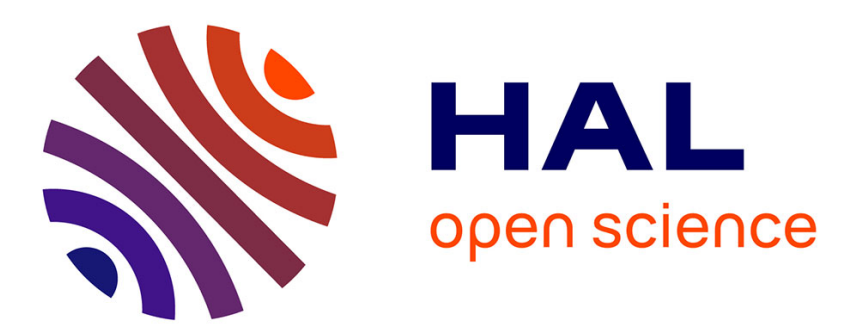

\title{
A survey of indicators for reproductive endocrine disruption in (killifish) at selected sites in the Chesapeake Bay
}

Anthony S. Pait, Judd O. Nelson

\section{- To cite this version:}

Anthony S. Pait, Judd O. Nelson. A survey of indicators for reproductive endocrine disruption in (killifish) at selected sites in the Chesapeake Bay. Marine Environmental Research, 2009, 68 (4), pp.170. 10.1016/j.marenvres.2009.06.006 . hal-00563084

\section{HAL Id: hal-00563084 \\ https://hal.science/hal-00563084}

Submitted on 4 Feb 2011

HAL is a multi-disciplinary open access archive for the deposit and dissemination of scientific research documents, whether they are published or not. The documents may come from teaching and research institutions in France or abroad, or from public or private research centers.
L'archive ouverte pluridisciplinaire HAL, est destinée au dépôt et à la diffusion de documents scientifiques de niveau recherche, publiés ou non, émanant des établissements d'enseignement et de recherche français ou étrangers, des laboratoires publics ou privés. 


\section{Accepted Manuscript}

A survey of indicators for reproductive endocrine disruption in Fundulus heteroclitus (killifish) at selected sites in the Chesapeake Bay

Anthony S. Pait, Judd O. Nelson

PII:

S0141-1136(09)00067-1

DOI:

10.1016/j.marenvres.2009.06.006

Reference:

MERE 3344

To appear in:

Marine Environmental Research

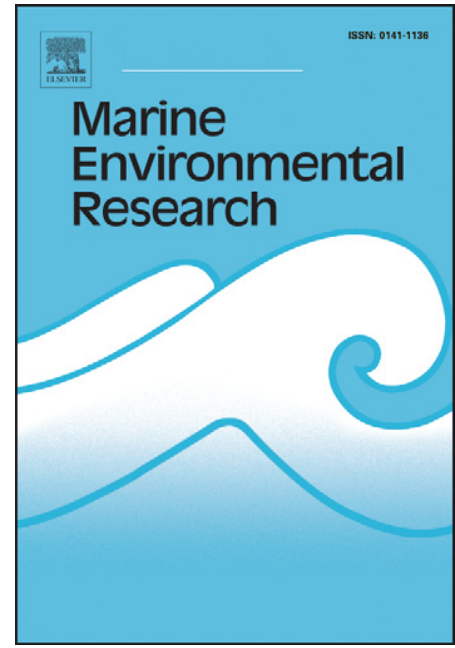

Received Date: $\quad 14$ April 2008

Revised Date: $\quad 26$ March 2009

Accepted Date: $\quad 2$ June 2009

Please cite this article as: Pait, A.S., Nelson, J.O., A survey of indicators for reproductive endocrine disruption in Fundulus heteroclitus (killifish) at selected sites in the Chesapeake Bay, Marine Environmental Research (2009), doi: 10.1016/j.marenvres.2009.06.006

This is a PDF file of an unedited manuscript that has been accepted for publication. As a service to our customers we are providing this early version of the manuscript. The manuscript will undergo copyediting, typesetting, and review of the resulting proof before it is published in its final form. Please note that during the production process errors may be discovered which could affect the content, and all legal disclaimers that apply to the journal pertain. 
1 A survey of indicators for reproductive endocrine disruption in Fundulus heteroclitus (killifish) at selected sites in the Chesapeake Bay

Anthony S. Pait ${ }^{\mathrm{a} *}$ and Judd O. Nelson ${ }^{\mathrm{b}}$

${ }^{a}$ NOAA, National Centers for Coastal Ocean Science, 1305 East/West Highway, Silver Spring, MD 20910

${ }^{\mathrm{b}}$ University of Maryland, College Park, MD 20742

*Corresponding author. Tel: (301) 713.3028; Fax: (301) 713.4384; email: tony.pait@ noaa.gov

Abstract—Plasma vitellogenin and related parameters in the killifish Fundulus heteroclitus were measured at selected sites in the Chesapeake Bay. In males, vitellogenin was above the detection limit $14 \%$ of the time, and detections did not differ between sites or seasons. Few differences in plasma vitellogenin levels were found between sites during fall in either male or female $F$. heteroclitus, the time of natural gonadal regression for this species. There was some variation in the ratio of male to female $F$. heteroclitus, but was not consistent at most sites.

Significant negative correlations were found between reported sediment polycyclic aromatic hydrocarbons (PAHs) and GSI, and PAHs and plasma vitellogenin in females in both Spring 1999 and Spring 2000. Gonadal anomalies in F. heteroclitus included slight reductions in certain tissue types. Overall, reproductive endocrine disruption in the killifish $F$. heteroclitus at the sites sampled in the Chesapeake Bay appeared somewhat minimal.

Keywords: Fundulus heteroclitus, killifish, Chesapeake Bay, endocrine disruption, vitellogenin, estuaries 
1

\section{1. Introduction}

3 Endocrine disrupting compounds (EDCs) are exogenous agents that cause adverse health effects

4 in an intact organism or its progeny, subsequent to changes in endocrine function (European

5 Commission, 1996). The occurrence of wildlife populations, particularly in the aquatic

6 environment, exhibiting effects thought to be associated with endocrine disruption has prompted

7 a significant amount of research to determine the extent and severity of impacts. A number of

8 studies have found effects in fish from various locations (Jobling et al., 1998; Hinck et al., 2007;

9 Blazer et al., 2007; Kleinkauf et al., 2004; Purdom et al., 1994; Harries et al., 1997; Lye et al., 10 1998; Allen et al., 1999; Collier et al., 1998; Scott et al., 2007; Kleinkauf et al., 2004).

12 EDCs include such diverse chemical groups as the alkylphenol polyethoxylate surfactants

13 (Jobling and Sumpter, 1993), polycyclic aromatic hydrocarbons or PAHs (Anderson et al., 1996;

14 Santodonato, 1997), the industrial intermediate bisphenol-A (Sumpter and Jobling, 1995),

15 polychlorinated biphenyls (PCBs) (Thomas, 1989), and certain trace elements (Ruby et al., 2000;

16 Thomas, 1989). There is also acknowledgement that when present in the aquatic environment as

17 is sometimes seen adjacent to sewage treatment plants (STPs), natural and synthetic estrogens

18 can contribute significantly to observed effects (Jobling et al., 2007; Purdom et al., 1994; Harries

19 et al., 1997).

21 Much of the research to date on endocrine disruption has focused on reproductive effects. Part

22 of the impetus for investigations with fish can be traced back to casual observations by anglers

23 in the mid-1980s of hermaphrodite roach (Rutilus rutilus) inhabiting STP lagoons in the U.K. 
1 (Routledge et al., 1998). Since then, reproductive effects observed in wild fish have ranged from

2 the presence of biomarkers of exposure, to changes in gonadal structure that would likely impair 3 reproduction.

4

5 Vitellogenin has become one of the most widely used biomarkers of exposure to EDCs. In egg

6 laying fish, this phosphoglycolipoprotein produced by the liver is the precursor of egg yolk

7 (Anderson et al., 1996). Although vitellogenin is typically associated with females, male fish

8 also possess hepatic estrogen receptors, and the presence of elevated levels of vitellogenin in

9 males has been used as an indicator of exposure to estrogen or estrogenic compounds (Sumpter

10 and Jobling, 1995). Purdom et al. (1994) found clear evidence of increased levels of plasma

11 vitellogenin in both sexes of rainbow trout (Oncorhynchus mykiss) exposed to STP effluents in

12 the U.K. In addition, the presence of intersex (presence of ovotestes) roach in a number of rivers

13 in the U.K. has been linked to exposure to STP effluents (Jobling et al., 1998). Endocrine

14 disruption has also been found in fish in the estuarine and marine environments, and in some

15 cases, effects have been linked to fish migration patterns (Kirby et al., 2004; Kleinkauf et al., 16 2004) or possible accumulation of estrogenic compounds through the food chain (Scott et al.,

17 2006; Scott et al., 2007). Finally, there is recent evidence that upgrades to STP treatment

18 processes can result in reduced levels of estrogenic contamination and associated endocrine

19 disruption (Kirby et al., 2004; Kleinkauf et al., 2004).

21 Studies have also linked organic chemical contamination with effects on the endocrine system in

22 fish. Female English sole (Parophrys vetulus) from a contaminated area in Puget Sound had significantly lower levels of $17 \beta$-estradiol compared with those from less contaminated sites 
1 (Johnson et al., 1988). In addition, inhibited gonadal development was found in this same

2 species in an area of Puget Sound heavily contaminated with PAHs (Collier et al., 1998). 3

4 This paper presents the results of a survey of plasma vitellogenin and related parameters in the

5 killifish Fundulus heteroclitus, a common inhabitant of the Chesapeake Bay. Pait and Nelson

6 (2003) demonstrated that male $F$. heteroclitus respond to a number of estrogenic EDCs in the

7 laboratory, producing plasma vitellogenin in a dose dependant manner. F. heteroclitus is a

8 ubiquitous, nonmigratory species inhabiting salt, brackish, and occasionally freshwater marshes

9 from Nova Scotia to northeast Florida, and is found characteristically close to shore (Abraham,

10 1985). Bigelow and Schroeder (1953) called F. heteroclitus "one of the most stationary of

11 fishes". Because $F$. heteroclitus is a nearshore, nonmigratory, and relatively nonmobile species,

12 effects seen in the field would likely be related to conditions, activities or events occurring in

13 that location. For this study a second species of fish, the sheepshead minnow (Cyprinodon

14 variegatus), was collected when available at the same sites as F. heteroclitus, in order to

15 compare vitellogenin concentrations in males of another species. Hemmer et al. (2001) showed

16 that male $C$. variegatus readily produce vitellogenin when exposed to estrogenic EDCs.

19 2. Materials and Methods

20 2.1. Sampling sites

21 Fish were sampled from a total of eight sites in the middle and upper portions of the Chesapeake

22 Bay (Figure 1). Sites ranged from pristine (reference) to industrialized, urbanized and

23 agricultural areas, to sites influenced by discharges from STPs. Industrial activities near the 
1 sampling sites in Baltimore (Fort Armistead, Patapsco River and Stonehouse Cove) included

2 petroleum bulk storage, organic chemical and plastics manufacture, sewage treatment and a

3 landfill. The Back River site in Baltimore County was located $1.7 \mathrm{~km}$ southeast of the Back

4 River Wastewater Treatment Plant, which discharges approximately 150 million gallons of

5 secondary treated water per day to the river. The primary reference site chosen for this study

6 was Beaverdam Creek (Figure 1), located on the eastern shore of the Chesapeake Bay. Together

7 with the Taylor Wildlife Management Area and the Blackwater National Wildlife Refuge, the

8 area of marsh is approximately $100 \mathrm{~km}^{2}$. There were no dwellings or commercial developments

9 within $5 \mathrm{~km}$ of the site. A second reference site was located at the Point Lookout State Park at

10 the confluence of the Potomac River and the Chesapeake Bay.

\subsection{Sample collection}

13 Fish were collected twice a year, between Fall 1998 and Spring 2000, once in spring/summer,

14 the reproductive season for both $F$. heteroclitus and $C$. variegatus, and again in fall after

15 reproduction had ceased. Sites were sampled up to four times over the course of the study.

16 Stonehouse Cove in Baltimore was only sampled once as fish were not found during other visits;

17 Beaverdam Creek was not sampled in Fall 1998. F. heteroclitus were collected using standard

18 minnow traps (Frabill, Inc., Allenton, WI) baited with bread. Traps were set from shore or

19 placed in the salt marsh at a depth of 1 meter or less from a canoe. The traps were checked after

2030 minutes, typically long enough to collect between 50 and $200 \mathrm{~F}$. heteroclitus. Ten adults of

21 each sex were then selected and placed in separate aerated buckets and brought back to the

22 laboratory, typically within two hours for processing. The remaining fish in the traps were sexed

23 and then returned to their habitat. The average weight of male F. heteroclitus brought back to 
1 the laboratory was $6.93 \mathrm{~g}$, average length was $8.0 \mathrm{~cm}$; the average weight of females was $8.01 \mathrm{~g}$,

2 average length $8.3 \mathrm{~cm}$.

3

4 During spring/summer, $F$. heteroclitus were collected within two days of the full moon in the

5 months of April, May and June. Gonadal development in F. heteroclitus has been shown to

6 peak during this time of year in the mid-Atlantic (Taylor et al., 1979). Fall sampling occurred

7 from late October to early November, with all sites sampled within a two-week period.

9 When available, males of a second species of fish, $C$. variegatus were collected at the same sites 10 as F. heteroclitus in order to compare vitellogenin in another species. Male C. variegatus have

11 been shown to readily produce vitellogenin when exposed to estrogenic EDCs (Hemmer et al.,

12 2001). If male $C$. variegatus from a sampling site contained elevated levels of plasma

13 vitellogenin, while vitellogenin levels in male $F$. heteroclitus from the same site were

14 significantly lower or below the detection level, this would be evidence that $C$. variegatus was

15 more sensitive than $F$. heteroclitus to the estrogenic EDCs present at the site. Male $C$.

16 variegatus were found in sufficient numbers at three of the same sites established for $F$.

17 heteroclitus including Patapsco River, Fort Armistead and Beaverdam Creek. The same

18 minnow traps were used for C. variegatus.

\subsection{Parameters measured}

21 Blood samples were taken using heparinized micro-hematocrit capillary tubes, and spun at

$2211,500 \mathrm{rpm}$. Plasma vitellogenin was quantified using a direct enzyme-linked immunosorbent assay (ELISA). A monoclonal antibody (MAb), specific for $F$. heteroclitus vitellogenin 
1 (5F8(HL1562)) developed by the Interdisciplinary Center for Biotechnology of the University of

2 Florida, was used in the ELISA. The antibody was tested and found to react specifically with $F$.

3 heteroclitus vitellogenin, and not other male plasma proteins (K. Kroll, pers. comm.).

4

5 A brief description of the direct ELISA protocol follows, and is essentially that developed and

6 used by a number of researchers (Denslow, et al., 1999; Bowman et al., 2000). Standards or

7 samples (unknown) in triplicate were first coated (50 $\mu 1)$ onto 96 well microplates (Dynatech

8 Laboratories, Inc., Chantilly, VA) in phosphate buffered saline with sodium azide (PBSZ).

9 Sample dilutions ranged from 1:500 to 1:25,000. Vitellogenin standards ranged from 0.01 to

$101.0 \mu \mathrm{g} \mathrm{ml}^{-1}$. Control (containing no vitellogenin) male plasma was added to the standards and

11 processed in the same way as samples. Plated samples and standards were allowed to incubate

12 overnight at $4^{\circ} \mathrm{C}$ in a humidified chamber, followed by washing with PBSZ. Plates were then

13 blocked, washed again with PBSZ followed by addition of the MAb and incubation again

14 overnight at $4^{\circ} \mathrm{C}$. Following this, plates were again washed and a second antibody, biotinylated

15 anti-mouse IgG (Pierce Chemical Company, Rockford, IL), was added followed by washing and

16 addition of strepavidin-alkaline phosphatase (Pierce Chemical Company, Rockford, IL). $p$ -

17 Nitrophenyl phosphate (pNPP) disodium (Sigma Chemical Company, St. Louis, MO) was then

18 added to each well after a final wash. The microplates were read at $405 \mathrm{~nm}$ on a

19 SPECTRAmax ${ }^{\circledR}$ PLUS (Molecular Devices Corporation, Sunnyvale, CA) spectrophotometer,

20 and the standard curve fit using a quadratic equation. The detection limit for the ELISA was 5

$21 \mu \mathrm{g} \mathrm{ml}^{-1}$. Plasma vitellogenin in male C. variegatus was analyzed by the University of Florida

22 using the same methodology as F. heteroclitus, and a MAb specific for C. variegatus. 
1 In addition to measuring plasma vitellogenin, the gonadosomatic index (gonad weight/body

2 weight X 100) or GSI, and the hepatosomatic index (liver weight/body weight X 100) or HSI

3 were calculated. The GSI has been used to assess the impact of EDCs in fish, particularly during 4 the period of gonadal recrudescence (Harries et al., 1997; Jobling et al., 1996). The condition 5 index or CI was calculated as $\mathrm{CI}=\mathrm{W} / \mathrm{L}^{3}$ according to Mezin and Hale (2000), where $\mathrm{W}$ is the 6 weight (g) multiplied by 100 , and $\mathrm{L}$ is length in $\mathrm{cm}$. 7

8 Gonadal tissues from male and female F. heteroclitus collected in Fall 1998 and Spring 1999

9 were assessed for gonadal anomalies. Tissues were fixed in Bouin's Fluid (Fisher Scientific,

10 Pittsburgh, PA), dehydrated with ethanol, cleared with chloroform (J.T. Baker, Inc.,

11 Phillipsburg, NJ), and embedded in Paraplast ${ }^{\circledR}$ Plus (Oxford Labware, St. Louis, MO).

12 Embedded tissues were transversely sectioned at 3 to $5 \mu \mathrm{m}$ and stained with hematoxylin and

13 eosin (Fisher Scientific, Pittsburgh, PA). Tissue sections were taken from the center of the

14 gonad. Microscopic (Leica DMR, Wetzel, Germany) examination (25x to 200x) of tissues from

15 males was carried out to determine the presence of primary oocytes or oviducts in the testes

16 (ovotestes), vacuolization of spermatogenic tissues, and thickening of interstitial tissues, all

17 effects seen in impacted populations of wild fish (Jobling et al., 1998; Lye et al., 1998).

18 Measurement of the cross sectional area of the gonad, spermatogenic tissue, efferent ducts, and

19 spermatids/spermatozoa were made using Image-Pro® Plus (Media Cybernetics, Silver Spring,

20 MD) digitizing software. It has been shown that spermatogenic lobule diameters in the common

21 carp (Cyprinus carpio) are reduced by exposure to 4-(tert-pentyl)phenol (Gimeno et al., 1998).

22 In F. heteroclitus, diameters of the spermatogenic tubules were measured to assess differences

23 that might exist in fish between sites. 
1

2 In female $F$. heteroclitus, oocytes were classified as to the stage of development (primary, early

3 vitellogenic, late vitellogenic, mature, or atretic) according to the rating system described by

4 Taylor and DiMichele (1980). All oocytes in a cross section were counted, and the oocytes in

5 each stage were compared between sites and seasons. The ratio of male to female $F$.

6 heteroclitus found in the traps at each sampling site was also recorded.

7

8 Finally, F. heteroclitus tissues from Spring 1999 were analyzed by the Environmental Quality

9 Laboratory of the U.S. Department of Agriculture (Beltsville, MD) for 4-nonylphenol,

10 nonylphenol monoethoxylate (NP1EO), and nonylphenol diethoxylate (NP2EO). Pooled whole

11 fish samples were extracted using accelerated solvent extraction (ASE), followed by cleanup

12 with aminopropylsilica. Extracts were derivatized with pentafluorobenzoyl chloride and

13 analyzed by GC/NCI-MS in the SIM mode.

14

15

16 All data were analyzed using JMP® statistical software (SAS Institute, Cary, NC). Data were

17 first tested for normality (Shapiro-Wilks). When data were found to be normally distributed

18 (e.g., GSI in male and female F. heteroclitus in Spring 1999 and 2000), an ANOVA was run

19 followed by pairwise comparisons (Tukey-Kramer HSD). Data that did not meet the condition

20 of normality (e.g., HSI in male and female F. heteroclitus in Spring 2000) were first ranked,

21 followed by an ANOVA and pairwise comparisons on the ranked data. Some vitellogenin data

22 sets, including all of the samples from male $F$. heteroclitus, and fall samples from female $F$.

23 heteroclitus contained many nondetects. This data was analyzed using the methodology found 
1 in Zar (1999). Data were first ranked from low to high; ties (e.g., nondetects) received the same

2 rank number, and the ANOVA run on the ranked data. Vitellogenin in female $F$. heteroclitus

3 collected during the spring were all above the detection limit, but did not meet the conditions of

4 normality. Data were first ranked before the ANOVA and pairwise comparisons were made.

5 Finally, a contingency table analysis was used to assess variations in the male/female ratio

6 between sites. Significance was reported at $p<0.05$.

7

8 A number of studies (Collier et al., 1998; Anderson et al., 1996; Thomas, 1988) have shown that

9 contaminants can negatively impact endocrine function, particularly in terms of gonadal

10 development. In the current study, a number of nonparametric Spearman's rank correlation

11 coefficients were generated to assess whether there was an association between reported

12 sediment contamination and selected parameters in $F$. heteroclitus. To do this, published data

13 on contaminant levels in sediments adjacent to the sampling sites were assembled from readily

14 available sources (Ashley and Baker, 1999; EPA, 2000). Sediment levels for 12 PAHs, five

15 PCBs, and two trace elements (cadmium and chromium) were found in the literature for six of

16 the sites where F. heteroclitus were collected. The sums of the inventoried contaminants by

17 class (i.e., PAHsum, PCBsum) along with the two trace elements were used as indicators of the

18 relative level of contamination between sites. Nonparametric correlation coefficients were

19 generated to look at correlations between GSI, vitellogenin, fish weight and length, and the

20 contaminants. An analysis was also carried out to group the data from those sites that had higher

21 reported levels of contaminants versus those areas with lower contaminant levels to see if

22 vitellogenin, GSI or HSI might vary by reported level of contamination. 
2 3. Results

3 3.1. Vitellogenin

4 Results of the plasma vitellogenin analysis in male $F$. heteroclitus are shown in Figure 2. There

5 were no significant differences between years within a season for male $F$. heteroclitus, so the

6 data were combined. Approximately $14 \%$ of the males tested had plasma vitellogenin levels

7 above the detection limit. The highest concentration of vitellogenin detected in a male $F$.

8 heteroclitus during this study was $580 \mu \mathrm{g} \mathrm{ml}^{-1}$ at the Choptank River site (agricultural area). An

9 ANOVA on the ranked male $F$. heteroclitus vitellogenin data revealed no significant differences

10 between sites during the fall $(p=0.6297)$ or spring $(p=0.1616)$ samplings, and there were no

11 significant differences in vitellogenin concentration in male $F$. heteroclitus between any of the

12 sites over the course of the study $(p=0.5412)$. There were also no differences in vitellogenin

13 concentration in males $(p=0.1072)$ or the percent detections $(p=0.2092)$ between seasons.

14 Finally, vitellogenin in males $F$. heteroclitus was not significantly correlated with either fish

15 weight $(p=0.4396)$ or length $(p=0.1927)$.

16

17 As mentioned, sites were also classified as being either contaminated (e.g., Fort Armistead, Back

18 River, Patapsco River, and Annapolis) or uncontaminated (e.g., Beaverdam Creek and Point

19 Lookout), based on the available sediment chemical contaminant data. An analysis of the

20 ranked data indicated no difference in male $F$. heteroclitus vitellogenin concentration between

21 contaminated and uncontaminated sites during the course of the study $(p=0.3217)$. 
1 For this study, male $C$. variegatus were also collected when available, at the same sites as $F$.

2 heteroclitus, in order to compare vitellogenin levels in males of another species. As noted, if $C$.

3 variegatus had elevated levels of vitellogenin, but $F$. heteroclitus had lower or levels below the 4 assay detection limits, this would be evidence not only for the presence of estrogenic EDCs in

5 the environment, but also a greater sensitivity of $C$. variegatus to the EDCs present. However,

6 only $5 \%$ of $C$. variegatus plasma samples contained detectable levels of vitellogenin (data not

7 shown), less than that for male $F$. heteroclitus. There were also no significant differences in

8 plasma vitellogenin between sites $(p=0.2016)$ or seasons $(p=0.0779)$ for male $C$. variegatus.

9 Finally, there were no significant differences in plasma vitellogenin between male $F$.

10 heteroclitus and male $C$. variegatus at the sites where both species were sampled $(p=0.3302)$.

12 Plasma vitellogenin detected in female $F$. heteroclitus during the spring collections is shown in

13 Figure 3. As expected, plasma vitellogenin in females was higher during the reproductive

14 periods. In Spring 1999, an analysis of the ranked vitellogenin levels in female F. heteroclitus

15 showed significant differences between sites $(p<0.001)$, and the pairwise comparisons

16 indicated significantly lower vitellogenin in females collected from Fort Armistead, Patapsco

17 River and Choptank River compared to Beaverdam Creek. In Spring 2000, $(p<0.001)$ however,

18 females from Back River and Choptank River had significantly higher vitellogenin levels than

19 females from Beaverdam Creek. Vitellogenin levels in female F. heteroclitus collected during

20 the fall were low. The average concentration was $40 \pm 10 \mu \mathrm{g} \mathrm{ml}^{-1}$ (mean $\pm \mathrm{SEM}$, data not

21 shown). Fifty-four percent of fall plasma samples from female $F$. heteroclitus were below the

22 ELISA detection limit for vitellogenin. ANOVAs on the ranked data indicated no significant 
1 difference in the concentrations of vitellogenin in female $F$. heteroclitus between sites in Fall

21998 or Fall 1999.

3

\subsection{Gonadosomatic index}

5 There were significant differences in the male GSIs in Spring $1999(p<0.0001)$ and Spring

$62000(p<0.0001)$ as shown in Table 1. In Spring 1999 male F. heteroclitus from Back River,

7 Fort Armistead, Patapsco River and Choptank River had significantly lower GSIs than males

8 from Beaverdam Creek. In Spring 2000, however, males from Annapolis and Patapsco River

9 had GSIs significantly higher than those from Beaverdam Creek. In Fall 1998 and 1999, there

10 were no significant differences in the male GSIs between the reference and other sites (data not

11 shown).

12

13 GSIs also varied by site for female $F$. heteroclitus in both Spring $1999(p<0.0001)$ and Spring

$142000(p<0.0001)$. In Spring 1999, female F. heteroclitus from Fort Armistead had GSIs

15 significantly lower than females from Beaverdam Creek (Table 1). In Spring 2000, females

16 from Fort Armistead again had significantly lower GSIs than females from Beaverdam Creek;

17 females from Back River had GSIs significantly higher.

193.3 Hepatosomatic and condition indices

20 In Spring 1999, there were no significant differences $(p>0.05)$ in male $F$. heteroclitus HSIs

21 between sites (Table 1). In Spring $2000(p<0.001)$, an analysis of the ranked data indicated that

22 HSIs in males from Back River and Annapolis were significantly higher than males from 
1 Beaverdam Creek. In Spring $1999(p<0.001)$, Fort Armistead males had a significantly lower

2 CI; the same was true in Spring 2000.

3

4 An analysis of the ranked data from Spring 1999 indicated that none of the HSIs in female $F$.

5 heteroclitus were significantly different from the Beaverdam Creek reference site. An analysis

6 of the ranked Spring $2000(p<0.0001)$, data indicated that females from two sites - Back River

7 and Annapolis had significantly higher HSIs than fish from Beaverdam Creek. Female CIs

8 varied by site in Spring $1999(p<0.0001)$ with Back River females having higher CIs than those

9 from Beaverdam Creek reference site. In Spring $2000(p<0.0001)$, female $F$. heteroclitus from

10 Fort Armistead had significantly lower CIs than those from Beaverdam Creek.

123.4 Residues of 4-nonylphenol in $\underline{F}$. heteroclitus

13 Although 4-nonylphenol $\left(23 \mathrm{ng} \mathrm{g}^{-1}\right)$ detected in the blanks prevented an assessment in fish

14 tissue, the blanks were free of the monoethoxylate (NP1EO) and diethoxylate (NP2EO). Values

15 for NP1EO in the tissues ranged from 6 to $25 \mathrm{ng} \mathrm{g}^{-1}$ and were low compared to results obtained

16 for other species of fish (C.A. Rice and J. Loyo-Rosales, personal communication); NP2EO was

17 not found in any of the fish tissues analyzed.

193.5 Correlations with sediment contaminants

20 In Spring 1999, there was a significant negative correlation between reported concentrations of

21 PAHs and PCBs in adjacent sediments and GSI in male $F$. heteroclitus (Table 2). The strongest

22 was between sediment PAHs and GSI in Spring $1999(p<0.05)$. In Spring 2000, there were no 
1 significant negative correlations between PAHs or PCBs and GSI in male F. heteroclitus (Table

$22)$.

3

4 The spring correlations for female $F$. heteroclitus are also shown in Table 2. A significant 5 negative correlation existed between GSI and sediment PAHs $(p<0.01)$, in Spring 1999, and 6 also in Spring $2000(p<0.001)$. Likewise, there was a significant negative correlation between

7 vitellogenin and PAHs in both Spring $1999(p<0.0001)$ and Spring $2000(p<0.05)$. There

8 were no significant correlations with PCBs or the two metals for either year.

$10 \quad 3.6$ Histology

11 An examination of testicular tissue in F. heteroclitus from both Fall 1998 and Spring 1999

12 revealed only one gross anomaly in the fish examined (approximately 60 fish); severely

13 degraded testes in a fish from the Patapsco River site in Spring 1999. No ovotestes were found

14 in any F. heteroclitus. In Fall 1998 there were no significant differences between the reference

15 and other sites in terms of the relative contribution of spermatogenic tissue or efferent ducts to

16 total cross sectional area, or the average spermatogenic tubule diameter. In Spring 1999, male $F$.

17 heteroclitus from Fort Armistead, Choptank River and Patapsco River had a significantly ( $p<$

18 0.0001) lower percentage of spermatogenic tissue (ranked data) compared to Beaverdam Creek

19 fish, and a correspondingly higher proportion of efferent ducts (data not shown). There were no

20 differences between sites in terms of the relative amount of spermatids/spermatozoa or the

21 spermatogenic tubule diameter in Spring 1999. 
1 In Fall 1998, primary oocytes dominated the cross sections for female $F$. heteroclitus, followed

2 by early and late vitellogenic oocytes. No mature oocytes were found in any of the cross

3 sections examined from fish collected in Fall 1998. In Fall 1998 and Spring 1999, there were no

4 significant differences in oocyte types in the cross sections at any site compared with the 5 reference site.

6

$7 \quad 3.7$ Male/female ratios

8 The results of the contingency table analyses are shown in Table 3. Asterisks identify those sites

9 where the ratio of male to female fish was significantly different from the expected (50:50).

10 Four sites had significantly different male to female ratios at least once during the study. One of

11 these, Point Lookout, was a reference site. The Annapolis site was the only location sampled

12 where $F$. heteroclitus females consistently and significantly outnumbered males (Table 3 ).

16 4. Discussion

17 4.1. Plasma vitellogenin

18 Plasma vitellogenin levels in the majority of male $F$. heteroclitus $(86 \%)$ were below the

19 detection limit. The Back River and Fort Armistead sites are located near STPs. The Back

20 River site is approximately $1.7 \mathrm{~km}$ downstream of the Back River Sewage Treatment Plant; the

21 Fort Armistead site is approximately $4 \mathrm{~km}$ downstream of the Patapsco Sewage Treatment Plant.

22 Although relatively close to STPs, there was no indication that the concentration of plasma

23 vitellogenin was higher in males at these sites compared to the reference sites. This would 
1 appear to indicate that the environmental concentration of estrogenic EDCs were too low at the

2 sites to elicit a response in male $F$. heteroclitus. At the downstream locations where the fish

3 were sampled, dilution and biodegradation of estrogenic EDCs that occurs as noted by Williams 4 et al. (2003) may have played a role. In addition, Kirby et al. (2004) noted that an upgrade of an

5 STP in the United Kingdom to secondary treatment was associated with lower levels of

6 estrogenic EDCs and effects in fish. The Back River and Patapsco River STPs both have

7 secondary treatment of wastewater.

9 There was also no evidence of seasonal changes in the concentration of vitellogenin in male $F$.

10 heteroclitus. Kirby et al. (2004) and Kleinkauf et al. (2004) have shown strong seasonal

11 differences in vitellogenin concentration in male flounder (Platichthys flesus) in several

12 estuaries in the UK, and are thought to be related to the migration patterns of this species. Male

13 flounder move into the estuaries from marine waters in the summer and generally have relatively

14 low levels of vitellogenin (Kleinkauf et al., 2004). However, vitellogenin in males sampled in

15 the estuaries in late winter tend to be significantly higher, presumably due to exposure to

16 estrogenic compounds over the six month period the fish are resident in the estuaries (Kirby et

17 al., 2004). Because $F$. heteroclitus is a nonmigratory species (Bigelow and Schroeder, 1953), it

18 is perhaps not surprising that seasonal effects on vitellogenin concentration in males were not

19 observed.

21 The lack of significant differences in vitellogenin found in this study among sites was true not

22 only for male $F$. heteroclitus, but also for male $C$. variegatus. Higher or more frequent

23 detections of vitellogenin in male $C$. variegatus would have been evidence for a greater 
1 sensitivity to estrogenic EDCs present compared to $F$. heteroclitus. Although the concentration

2 of estrogenic EDCs was not quantified in the water column, the results would seem to indicate

3 that the levels of these estrogens were too low to elicit a significant response in either male $F$.

4 heteroclitus or male C. variegatus.

5

6 The lack of significant differences in plasma vitellogenin in male fish between sites is similar to

7 that found in a few other studies in the U.S. No indication of elevated vitellogenin was found in

8 male carp from the Mississippi River (Parks et al., 1997). Vitellogenin in male mosquitofish

9 (Gambusia affinis) downstream of a large STP near Birmingham, Alabama was also not elevated

10 (Angus et al., 2002). Goodbred et al. (1997) investigated reproductive endocrine disruption in

11 carp at 25 sites and two impoundments in the U.S. Overall, only $16 \%$ of male carp collected

12 had vitellogenin levels above the detection limit, similar to the $14 \%$ in male $F$. heteroclitus in

13 the current study. In their study, Goodbred et al. (1997) also detected vitellogenin in male carp

14 at several minimally contaminated locations. In the current study, vitellogenin was occasionally

15 detected in male $F$. heteroclitus at the reference sites. Goodbred et al. (1997) concluded that

16 male carp appear to have low background levels of vitellogenin naturally; the same may also be

17 true for $F$. heteroclitus.

19 Scott et al. (2006) and Scott et al. (2007) found a correlation between fish size (weight) and

20 vitellogenin in male cod (Gadus morhua) and male dab (Limanda limanda), respectively. They

21 hypothesized that these two oceanodromous species accumulate estrogenic EDCs over time

22 through the food chain, and that larger males have accumulated higher amounts, resulting in

23 higher vitellogenin levels. In male $F$. heteroclitus, however, there was no correlation between 
1 vitellogenin and size (weight and length) of the fish. Given the relatively short life span of $F$.

2 heteroclitus, estimated at a maximum of 4-5 years by Kneib and Stiven (1978), along with the

3 smaller size and different feeding habit of this species, the results are perhaps not surprising. 4

54.2 GSI and contaminants

6 An analysis of the data did reveal some significant associations between selected parameters in

$7 \quad$ F. heteroclitus and reported sediment contaminant concentrations during the spring samplings.

8 In female $F$. heteroclitus, there was a significant negative correlation between the GSI and PAHs

9 in both Spring 1999 and Spring 2000. In male $F$. heteroclitus, there was a significant negative

10 correlation between GSI and sediment PAHs in Spring 1999. A number of studies have shown

11 that contaminants can negatively impact gonadal development in fish. Thomas (1988) found

12 that benzo[ $[a]$ pyrene, in the diet of female Atlantic croaker (Micropogonias unduluatus), resulted

13 in significantly lower GSIs. Inhibited gonadal development in adult English sole has been

14 correlated with exposure to PAHs in sediments (Collier et al., 1998). From the current work, it

15 appears there may be an association between PAHs and GSIs in F. heteroclitus, particularly in

16 females, although additional work is needed to assess whether PAHs or some other chemicals or

17 environmental parameters were responsible.

\subsection{Plasma vitellogenin and contaminants}

20 The PAH $\beta$-napthoflavone has been found to depress vitellogenin synthesis in the liver of

21 juvenile rainbow trout (Anderson et al., 1996). Pereira et al. (1992) detected lower vitellogenin

22 levels in female winter flounder (Pleuronectes americanus) in an area of Boston Harbor

23 contaminated with PAHs and other contaminants. Vitellogenin production in female $F$. 
1 heteroclitus was also negatively correlated with sediment PAHs in the spring of both years.

2 Evidence for antiestrogenic and antiandrogenic effects in $F$. heteroclitus appeared to be stronger

3 in Spring 1999 than in Spring 2000. The reason for this is unknown. However, a drought in the 4 region reached its peak in Spring 1999, and along with higher temperatures encountered around 5 the time of sampling could have physiologically stressed the fish.

6

$7 \quad 4.4$ Male/female ratios

8 Hansen et al. (1998) stated that a preponderance of female fish in some waterways is of concern

9 to environmental regulators. In the current study, there was no clear pattern in deviations from a $1050: 50$ distribution of males to females between sites. A significant deviation from the expected

11 ratio occurred at one of the reference sites (Point Lookout). The only site where there were

12 consistently greater and significant numbers of females than males was Annapolis. However,

13 Annapolis did not produce a greater detection of plasma vitellogenin in males, nor did any of the

14 fish from the site contain ovotestes or other obvious gonadal anomalies.

16 Given the level of effects seen in this study, it is perhaps not surprising that the male/female

17 ratio was not revealing. If endocrine disruption in an area was so severe that $F$. heteroclitus

18 originally programmed to be male ultimately became female, a spectrum of endocrine-related

19 effects might be expected, including intersex fish. The results of the analysis indicating

20 significant, possibly natural variability in the ratio of males to females between sites and years

21 supports the general findings of this study. 


\section{Conclusions}

2 The goal of this study was to survey the killifish Fundulus heteroclitus at sites around the

3 Chesapeake for indictors of reproductive endocrine disruption. There were no significant

4 differences in concentrations of plasma vitellogenin in male $F$. heteroclitus between sites in

5 either the spring or fall samplings or between contaminated and uncontaminated sites. An

6 analysis of plasma vitellogenin in males of a second species (Cyprinodon variegatus), indicated

7 no difference in the concentration of vitellogenin compared with male $F$. heteroclitus at sites

8 where both species were sampled. No ovotestes were seen in the gonads of $F$. heteroclitus from

9 Fall 1998 or Spring 1999. There were some indications of antiestrogenic and antiandrogenic

10 effects, particularly in Spring 1999. Lower GSIs and plasma vitellogenin levels in female $F$.

11 heteroclitus were negatively correlated with reported sediment PAH concentrations in both

12 Spring 1999 and Spring 2000. In conclusion, overt reproductive endocrine disruption in the

13 killifish $F$. heteroclitus at the sites sampled in the Chesapeake Bay appeared minimal.

14 Additional work is needed, however, to further assess endocrine disruption in this and other

15 species in estuaries such as the Chesapeake Bay, incorporating factors such as land use and size

16 of the receiving waters, to better understand the effects of EDCs in coastal and marine waters of 17 the US

\section{Acknowledgements}

20 This work was supported by the National Oceanic and Atmospheric Administration and the

21 University of Maryland. The authors wish to thank Dr. Christopher Jeffrey and Dr. Larry Claflin 22 of NOAA for their help with the statistical analysis, Dr. Nancy Denslow and Kevin Kroll of the

23 University of Florida for the analysis of $C$. variegatus plasma samples, and Dr. Clifford Rice and 
1 Dr. Jorge Loyo-Rosales at the U.S. Department of Agriculture, Environmental Quality

2 Laboratory for the 4-nonylphenol analysis. Special thanks go to Bozena Kucewicz-Pait, Magda

3 Czarny and Wojtek Bejgerowski for their much appreciated assistance and company during

$4 \quad$ laboratory and field work.

5

\section{References}

7

8 Abraham, B.J., 1985. Species profiles: life histories and environmental requirements of coastal

9 fishes and invertebrates (Mid-Atlantic - mummichog and striped killifish. U.S. Fish and Wildlife

10 Service. Biological Report 82(11.40). U.S. Army Corps of Engineers, TR EL, 82-4. 23p.

12 Allen, Y., Scott, A. P., Matthiessen, P., Haworth, S., Thain, J. E., Feist, S., 1999. Survey of 13 estrogenic activity in United Kingdom estuarine and coastal waters and its effects on gonadal 14 development of the flounder Platichthys flesus. Environmental Toxicology and Chemistry 18, $1791-1800$

Anderson, J., Olsen, H., Matsumura, F., Hinton, D.E., 1996. In vivo modulation of 17ß-

estradiol induced vitellogenin synthesis and estrogen receptor in rainbow trout (Oncorhynchus mykiss) liver cells by b-napthoflavone. Toxicology and Applied Pharmacology 137, 210-218.

Angus, R.A., Weaver, S.A., Grizzle, J.M., Watson, R.D., 2002. Reproductive characteristics of 22 male mosquitofish (Gambusia affinis) inhabiting a small southeastern U.S. river receiving treated domestic sewage effluent. Environmental Toxicology and Chemistry 21, 1404-1409. 
1 Ashley, J.T.F., Baker, J.E., 1999. Hydrophobic organic contaminants in surficial sediments of

2 Baltimore Harbor: inventories and sources. Environmental Toxicology and Chemistry 18, 8383849

4

5 Bigelow, H.B., Schroeder, W.C., 1953. Fishes of the Gulf of Maine. U.S. Fish and Wildlife

6 Service Bulletin 53. 575p.

7

8 Blazer, V. S., Iwanowicz, L.R., Iwanowicz, D. D., Smith, D. R., Young, J. A., Hedrick, J. D.,

9 Foster, S. W., Reeser, S. J., 2007. Intersex (testicular oocytes) in smallmouth bass from the 10 Potomac River and selected nearby drainages. Journal of Aquatic Animal Health 19, 242-253.

11

12 Bowman, C.J., Kroll, K.J., Hemmer, M.J., Folmar, L.C., Denslow, N.D., 2000. Estrogen-

13 induced vitellogenin mRNA and protein in sheepshead minnow (Cyprinodon variegatus).

14 General and Comparative Endocrinology 120, 300-313.

16 Collier, T. K., Johnson, L. L., Stehr, C. M., Myers, M. S., Stein, J. E., 1998. A comprehensive

17 assessment of the impacts of contaminants on fish from an urban waterway. Marine

18 Environmental Research 49, 243-247.

20 Denslow, N.D., Chow, M.C., Kroll, K.J., Green, L., 1999. Vitellogenin as a biomarker of 21 exposure for estrogen or estrogen mimics. Ecotoxicology 8, 385-398. 
1 Environmental Protection Agency, 2000. Toxics Characterization Database. [Online]

2 Available http://chesapeakebay.net/info/toxdata.html.

3

4 European Commission, 1996. European workshop on the impact of endocrine disruptors on

5 human health and wildlife. Report EUR 17549, Environment and Climate Research Program,

6 European Commission.

7

8 Gimeno, S., Komen, H., Jobling, S., Sumpter, J., Bowmer, T., 1998. Demasculinisation of

9 sexually mature male common carp Cyprinus carpio, exposed to 4-tert-pentylphenol during

10 spermatogenesis. Aquatic Toxicology 43, 93-109.

12 Goodbred, S.L., Gilliom, R.J., Gross, T.S., Denslow, N.D., Bryant, W.L., Schoeb, T.R., 1997.

13 Reconnaissance of 17b-estradiol, 11-ketotesterone, vitellogenin, and gonad histopathology in

14 common carp of United States streams: potential for contaminant -induced endocrine disruption.

15 U.S. Geological Survey. Sacramento, California. Open-File 96-627. 47pp.

16

17 Hansen, P.D., Dizer, H., Hock, B., Marx, A., Sherry, J., McMaster, M., Blaise, C., 1998.

18 Vitellogenin - a biomarker for endocrine disrupters. Trends in Analytical Chemistry 17, 48-451.

20 Harries, J. E., Sheahan, D. A., Jobling, S., Matthiessen, P., Neall, P., Sumpter, J. P., Taylor, T., 21 Zaman, N., 1997. Estrogenic activity in five United Kingdom rivers detected by measurement of 22 vitellogenesis in caged male trout. Environmental Toxicology and Chemistry 16, 534-542. 
1 Hemmer, M.J., Hemmer, B.L., Bowman, C.J., Kroll, K.J., Folmar, L.C., Marcovich, D.,

2 Hoglund, M.D., Denslow, N.D., 2001. Effects of p-nonylphenol, methoxychlor, and endosulfan

3 on vitellogenin induction and expression in sheepshead minnow (Cyprinodon variegatus).

4 Environmental Toxicology and Chemistry 20, 336-343.

5

6 Hinck, J.E., Blazer, V.S., Denslow, N.D., Echols, K.R., Gross, T.S., May, T.W., Anderson, P.J.

7 Coyle, J.J., Tillitt, D.E., 2007. Chemical contaminants, health indicators, and reproductive

8 biomarker responses in fish from the Colorado River and its tributaries. Science of the Total

9 Environment 378, 376-402.

10

11 Jobling, S., Sheahan, D., Osborne, J.A., Matthiessen, P., Sumpter, J.P., 1996. Inhibition of

12 testicular growth in rainbow trout (Oncorhynchus mykiss) exposed to estrogenic alkylphenolic

13 chemicals. Environmental Toxicology and Chemistry 15, 194-202.

14

15 Jobling, S., Sumpter, J. P., 1993. Detergent components in sewage effluent are weakly

16 oestrogenic to fish: an in vitro study using rainbow trout (Oncorhynchus mykiss) hepatocytes.

17 Aquatic Toxicology 27, 361-372.

18

19 Jobling, S., Nolan, M., Tyler, C. R., Brightly, G., Sumpter, J. P., 1998. Widespread sexual

20 disruption in wild fish. Environmental Science and Technology 32, 2498-2506.

22 Jobling, S., Williams, R., Johnson, A., Taylor, A., Gross-Sorokin, M., Nolan, M., Tyler, C.R., 23 van Aerle, R., Santos, E., Brighty, G., 2007. Predicted exposures to steroid estrogens in UK 
1 rivers correlate with widespread sexual disruption in wild fish populations. Environmental

2 Health Perspectives, 114, 32-39.

3

4 Johnson, L.J., Casillas, E., Collier, T.K., McCain, B.B., Varanasi, U., 1988. Contaminant

5 effects on ovarian development in English sole (Parophrys vetulus) from Puget Sound,

6 Washington. Canadian Journal of Fisheries and Aquatic Science 45, 2133-2146.

7

8 Kleinkauf, A., Scott, A.P., Stewart, C., Simpson, M.G., Leah, R.T., 2004. Abnormally elevated

9 vtg concentrations in flounder (Platichthys flesus) from the Mercey Estuary (UK) - a continuing 10 problem. Ecotoxicology and Environmental Safety 58, 356-364.

12 Kirby, M.F., Allen, Y.T., Dyer, R.A., Feist, S.W., Katsiadaki, I., Matthiessen, P., Scott, A.P.,

13 Smith, A., Stentiford, G.D., Thain, J.E., Thomas, K.V., Tolhurst, L., Waldock, M.J., 2004.

14 Surveys of plasma vitellogenin and intersex in male flounder (Platichthys flesus) as measures of 15 endocrine disruption by estrogenic contamination in United Kingdom estuaries: temporal trends, 161996 to 2001.

18 Kneib, R. T., and A.E. Stiven, 1978. Growth, reproduction, and feeding of Fundulus heteroclitus

19 (L.) on a North Carolina salt marsh. Journal of Experimental Marine Biology and Ecology, 31, $20 \quad 121-140$.

22 Lye, C. M., Frid, C. L. J, Gill, M. E., 1998. Seasonal reproductive health of flounder Platichthys 23 flesus exposed to sewage effluent. Marine Ecology Progress Series 170, 249-260. 
1

2 Mezin, L.C., Hale, R.C., 2000. Effects of contaminated sediment on the epidermis of

3 mummichog, Fundulus heteroclitus. Environmental Toxicology and Chemistry 19, 2779-2787. 4

5 Pait, A.S., Nelson, J.O., 2003. Vitellogenesis in male Fundulus heteroclitus (killifish) induced

6 by selected estrogenic compounds. Aquatic Toxicology 64, 331-342.

7

8 Parks, L.G., Heppell, S.A., Shea, D., Sullivan, C.V., LeBlanc, G.A., 1997. Vitellogenin

9 detection in two cyprinid species using a competitive ELISA in laboratory and field studies.

10 Presented at the 18th Annual Meeting of the Society of Environmental Toxicology and

11 Chemistry, San Francisco, California, 16-20 November.

12

13 Pereira, J.J., Ziskowski, J. Mercaldo-Allen, R., Kuropat, C., Luedke, D., Gould, E., 1992.

14 Vitellogenin in winter flounder (Pleuronectes americanus) from Long Island Sound and Boston

15 Harbor. Estuaries 15, 289-297.

16

17 Purdom, C. E., Hardiman, P. A., Bye, V. J., Eno, N. C., Tyler, C. R. Sumpter, J. P., 1994.

18 Estrogenic effects of effluents from sewage treatment works. Chemical Ecology 8, 275-285.

20 Routledge, E.J., Sheahan, D., Desbrow, C., Brighty, G.C., Waldock, M., Sumpter J.P., 1998.

21 Identification of estrogenic chemicals of STW effluent. 2. In vivo responses in trout and roach.

22 Environmental Science and Technology 32, 1559-1565. 
1 Ruby, S.M., Hull, R., Anderson, P., 2000. Sublethal lead affects pituitary function of rainbow

2 trout during exogenous vitellogenesis. Archives of Environmental Contamination and

3 Toxicology $38,46-51$.

4

5 Santodonato, J., 1997. Review of estrogenic and antiestrogenic activity of polycyclic aromatic

6 hydrocarbons: relationship to carcinogenicity. Chemosphere 34, 835-848.

7

8 Scott, A.P, Katsiadaki, I., Witthames, P.R., Hylland, K., Davies, I.M., McIntosh, A.D., Thain, J.

9 2006. Vitellogenin in the blood plasma of male cod (Gadus morhua): a sign of oestrogenic

10 disruption in the open sea? Marine Environmental Research, 61. 149-170.

12 Scott, A.P., Sanders, M., Stentiford, G.D., Reese, R.A., Katsiadaki, I., 2007. Evidence for

13 estrogenic endocrine disruption in and offshore flatfish, the dab (Limanda limanda L.). Marine

14 Environmental Research 64, 128-148.

16 Sumpter, J.P., Jobling, S., 1995. Vitellogenesis as a biomarker for estrogenic contamination of 17 the aquatic environment. Environmental Health Perspectives 103(Suppl 7), 173-178.

19 Taylor, M.H., DiMichele, L., 1980. Ovarian changes during the lunar spawning cycle of

20 Fundulus heteroclitus. Copeia 1, 118-125.

22 Taylor, M.H., Leach, G.J., DiMichele, L., Levitan, W.M., Jacob, W.F., 1979. Lunar spawning cycle in the mummichog, Fundulus heteroclitus (Pisces: Cyprinodontidae). Copeia 2, 291-297. 
2 Thomas, P., 1989. Effects of Arochlor 1254 and cadmium on reproductive function and ovarian

3 growth in Atlantic croaker. Marine Environmental Research 28, 499-503.

4

5 Thomas, P., 1988. Reproductive endocrine function in female Atlantic croaker exposed to

6 pollutants. Marine Environmental Research 24, 179-183.

7

8 Williams, R.J., Johnson, A.C., Smith, J.J.L., Kanda, R., 2003. Steroid estrogen profiles along

9 river stretches arising from sewage treatment works discharges 37, 1744-1750.

10

11 Zar, J.H., 1999. Biostatistical Analysis. Prentice Hall, Upper Saddle River, New Jersey. 663pp. 


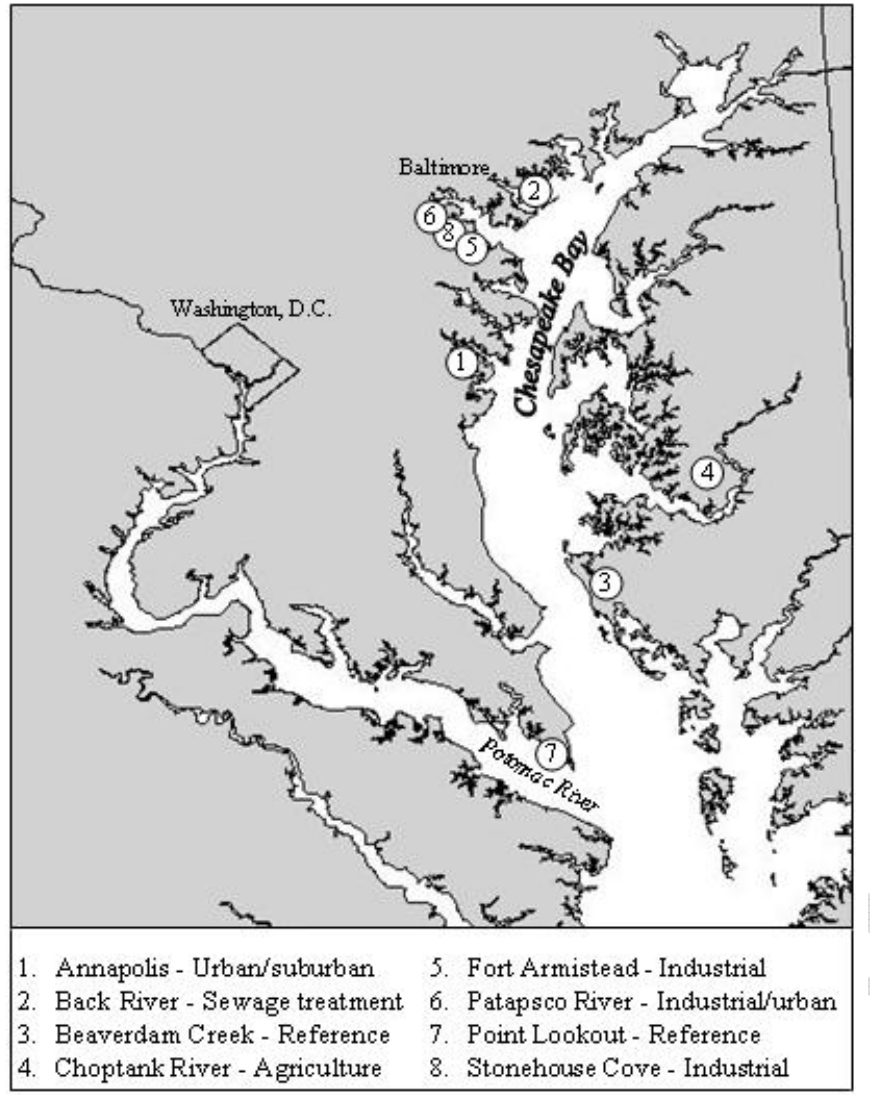

Figure 1. Collection sites for F. heteroclitus. 


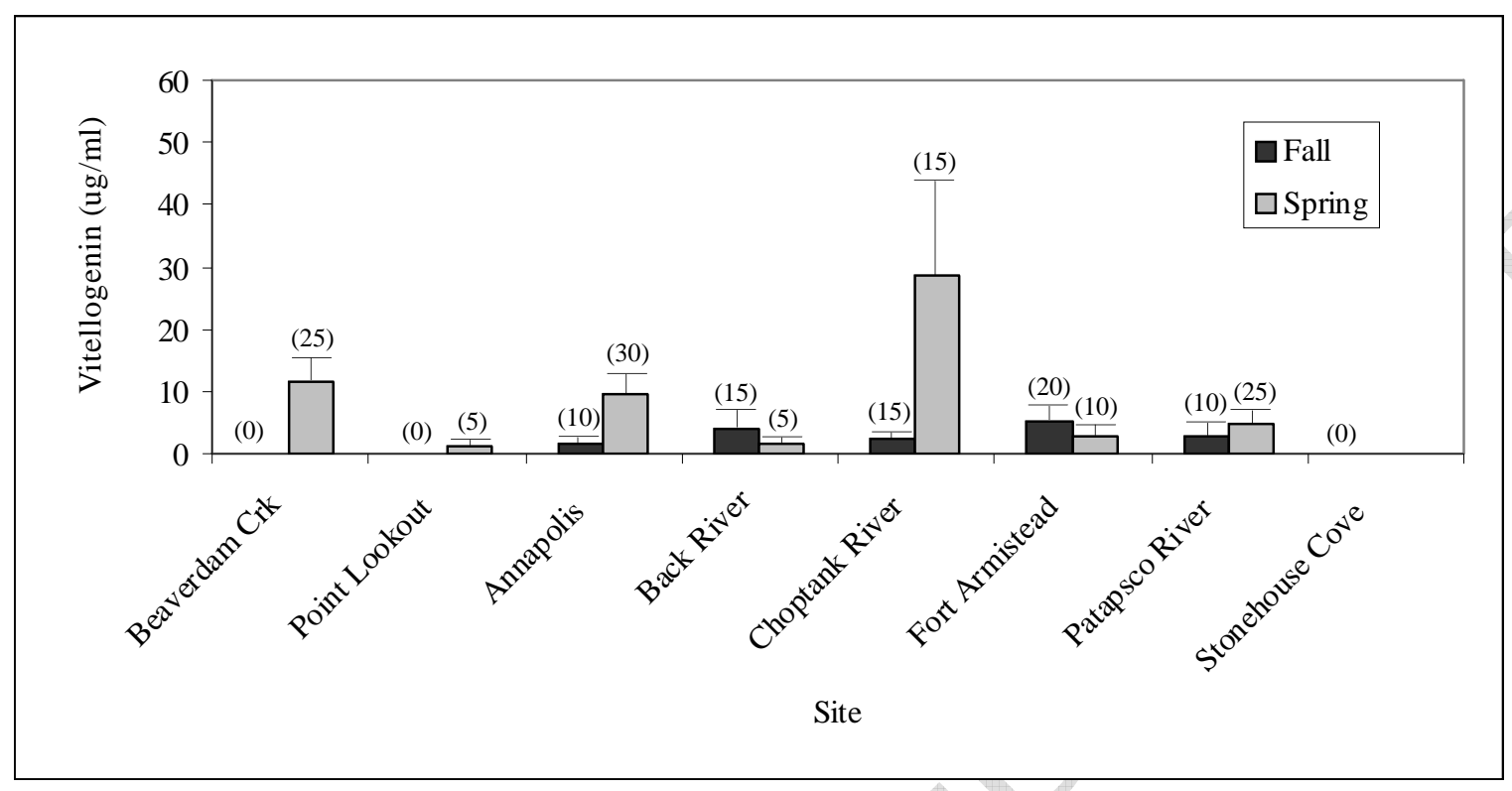

Figure 2. Vitellogenin detected in male $F$. heteroclitus. Values are the mean, error bars represent SEM. Values in parentheses represent the percentage of detections at the site during the season. $\mathrm{n}=10-20$. 


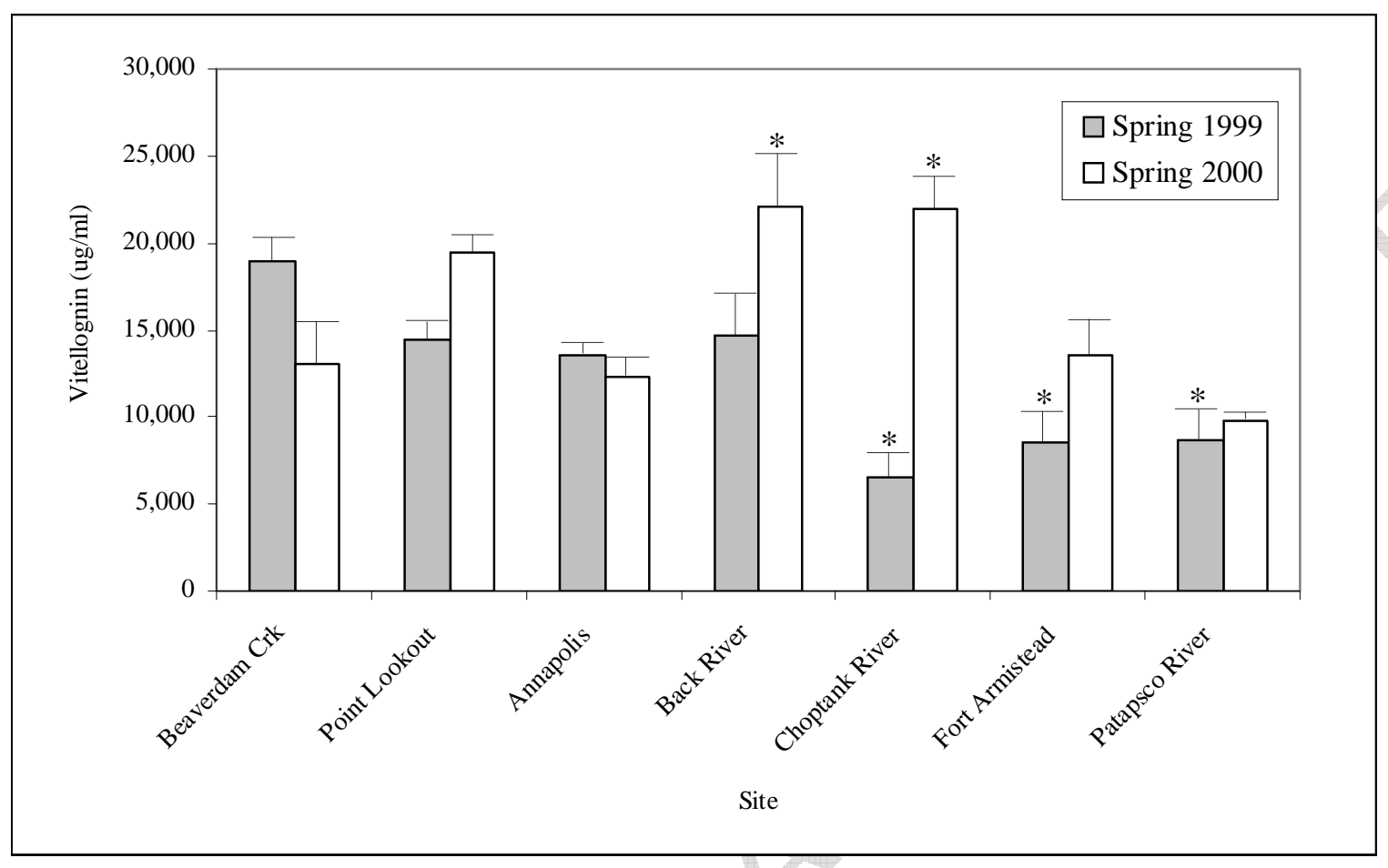

Figure 3. Vitellogenin detected in female $F$. heteroclitus. Values are the mean, error bars represent the SEM. Asterisks indicate those sites significantly different from Beaverdam Creek within a spring sampling. $n=10-20$. 
Table 1. Spring GSI, HSI and CI measurements made in F. heteroclitus .

\begin{tabular}{|c|c|c|c|c|c|c|c|}
\hline & \multicolumn{7}{|c|}{ Site } \\
\hline & $\begin{array}{c}\text { Beaverdam } \\
\text { Creek }\end{array}$ & Annapolis & Back River & $\begin{array}{c}\text { Choptank } \\
\text { River }\end{array}$ & $\begin{array}{c}\text { Fort } \\
\text { Armistead }\end{array}$ & $\begin{array}{c}\text { Patapsco } \\
\text { River }\end{array}$ & $\begin{array}{c}\text { Point } \\
\text { Lookout }\end{array}$ \\
\hline Male & & & & GSI & & & \\
\hline Spring 1999 & $\begin{array}{c}3.5 \\
( \pm 0.1)\end{array}$ & $\begin{array}{c}3.0 \\
( \pm 0.4)\end{array}$ & $\begin{array}{c}2.3^{*} \\
( \pm 0.3)\end{array}$ & $\begin{array}{c}1.9 * \\
( \pm 0.1)\end{array}$ & $\begin{array}{c}1.9^{*} \\
( \pm 0.3)\end{array}$ & $\begin{array}{c}1.8^{*} \\
( \pm 0.5)\end{array}$ & \\
\hline Spring 2000 & $\begin{array}{c}2.4 \\
( \pm 0.2)\end{array}$ & $\begin{array}{c}3.3^{*} \\
( \pm 0.2)\end{array}$ & $\begin{array}{c}2.3 \\
( \pm 0.1)\end{array}$ & $\begin{array}{c}1.9 \\
( \pm 0.1)\end{array}$ & $\begin{array}{c}2.3 \\
( \pm 0.2)\end{array}$ & $\begin{array}{c}3.1^{*} \\
( \pm 0.2)\end{array}$ & $\begin{array}{c}2.7 \\
( \pm 0.1)\end{array}$ \\
\hline Spring 1999 & $\begin{array}{c}1.5 \\
( \pm 0.1)\end{array}$ & $\begin{array}{c}1.9 \\
( \pm 0.2)\end{array}$ & $\begin{array}{c}1.8 \\
( \pm 0.1)\end{array}$ & $\begin{array}{l}\frac{\mathrm{HSI}}{1.5} \\
( \pm 0.2)\end{array}$ & $\begin{array}{c}1.6 \\
( \pm 0.2)\end{array}$ & $\begin{array}{c}1.5 \\
( \pm 0.1)\end{array}$ & - \\
\hline Spring 2000 & $\begin{array}{c}1.6 \\
( \pm 0.1)\end{array}$ & $\begin{array}{c}2.2^{*} \\
( \pm 0.1)\end{array}$ & $\begin{array}{c}2.4^{*} \\
( \pm 0.1)\end{array}$ & $\begin{array}{c}1.8 \\
( \pm 0.1)\end{array}$ & $\begin{array}{c}1.7 \\
( \pm 0.1)\end{array}$ & $\begin{array}{c}2.1 \\
( \pm 0.2)\end{array}$ & $\begin{array}{c}1.8 \\
( \pm 0.1)\end{array}$ \\
\hline Spring 1999 & $\begin{array}{c}1.3 \\
(<0.1)\end{array}$ & $\begin{array}{c}1.3 \\
(<0.1)\end{array}$ & $\begin{array}{c}1.3 \\
(<0.1)\end{array}$ & $\begin{array}{c}1.3 \\
(<0.1)\end{array}$ & $\begin{array}{l}1.2^{*} \\
(<0.1)\end{array}$ & $\begin{array}{c}1.3 \\
(<0.1)\end{array}$ & - \\
\hline Spring 2000 & $\begin{array}{c}1.3 \\
(<0.1)\end{array}$ & $\begin{array}{c}1.3 \\
(<0.1)\end{array}$ & $\begin{array}{c}1.3 \\
(<0.1)\end{array}$ & $\begin{array}{c}1.3 \\
(<0.1)\end{array}$ & $\begin{array}{l}1.1^{*} \\
(<0.1)\end{array}$ & $\begin{array}{c}1.3 \\
(<0.1)\end{array}$ & $\begin{array}{c}1.4 \\
(<0.1)\end{array}$ \\
\hline Female & & & & $\underline{\text { GSI }}$ & & & \\
\hline Spring 1999 & $\begin{array}{c}11.6 \\
( \pm 0.9)\end{array}$ & $\begin{array}{c}6.7 \\
( \pm 1.5)\end{array}$ & $\begin{array}{c}13.7 \\
( \pm 1.1)\end{array}$ & $\begin{array}{c}6.6 \\
( \pm 2.0)\end{array}$ & $\begin{array}{c}3.9^{*} \\
( \pm 0.6)\end{array}$ & $\begin{array}{c}9.6 \\
( \pm 1.8)\end{array}$ & - \\
\hline Spring 2000 & $\begin{array}{c}10.5 \\
( \pm 1.0)\end{array}$ & $\begin{array}{c}7.4 \\
( \pm 0.8)\end{array}$ & $\begin{array}{l}13.9 * \\
( \pm 0.5)\end{array}$ & $\begin{array}{c}7.8 \\
( \pm 0.7)\end{array}$ & $\begin{array}{c}6.2^{*} \\
( \pm 0.3)\end{array}$ & $\begin{array}{c}9.5 \\
( \pm 1.1)\end{array}$ & $\begin{array}{c}9.5 \\
( \pm 0.5)\end{array}$ \\
\hline Spring 1999 & $\begin{array}{c}2.4 \\
( \pm 0.1)\end{array}$ & $\begin{array}{c}2.5 \\
( \pm 0.2)\end{array}$ & $\begin{array}{c}3.4 \\
( \pm 0.2)\end{array}$ & $\begin{array}{l}\frac{\mathrm{HSI}}{2.0} \\
( \pm 0.2)\end{array}$ & $\begin{array}{c}2.0 \\
( \pm 0.2)\end{array}$ & $\begin{array}{c}2.2 \\
( \pm 0.2)\end{array}$ & - \\
\hline Spring & $\begin{array}{c}2.5 \\
( \pm 0.1)\end{array}$ & $\begin{array}{c}3.4^{*} \\
( \pm 0.1)\end{array}$ & $\begin{array}{c}4.5^{*} \\
( \pm 0.1)\end{array}$ & $\begin{array}{c}3.0 \\
( \pm 0.2)\end{array}$ & $\begin{array}{c}3.0 \\
( \pm 0.2)\end{array}$ & $\begin{array}{c}3.2 \\
( \pm 0.3)\end{array}$ & $\begin{array}{c}2.6 \\
( \pm 0.1)\end{array}$ \\
\hline Spring 1999 & $\begin{array}{c}1.3 \\
(<0.1)\end{array}$ & $\begin{array}{c}1.3 \\
(<0.1)\end{array}$ & $\begin{array}{c}1.5^{*} \\
(<0.1)\end{array}$ & $\begin{array}{l}\underline{\mathrm{CI}}_{1.3} \\
(<0.1)\end{array}$ & $\begin{array}{c}1.2 \\
( \pm 0.1)\end{array}$ & $\begin{array}{c}1.2 \\
(<0.1)\end{array}$ & - \\
\hline Spring 2000 & $\begin{array}{c}1.4 \\
(<0.1)\end{array}$ & $\begin{array}{c}1.4 \\
(<0.1)\end{array}$ & $\begin{array}{c}1.5 \\
(<0.1)\end{array}$ & $\begin{array}{c}1.3 \\
(<0.1)\end{array}$ & $\begin{array}{l}1.2^{*} \\
(<0.1)\end{array}$ & $\begin{array}{c}1.3 \\
(<0.1)\end{array}$ & $\begin{array}{c}1.4 \\
(<0.1)\end{array}$ \\
\hline
\end{tabular}

Asterisks indicate those sites significantly different from the Beaverdam Creek reference site at $\mathrm{p}<0.05$. Values in parentheses are SEM. GSI, gonadosomatic index; HSI, hepatosomatic index; CI, condition index; - , no data available. $\mathrm{n}=5-10$. 
Table 2. Spearman rank coefficients for $F$. heteroclitus.

\begin{tabular}{|c|c|c|}
\hline Variable 1 & Variable 2 & Spearman's $\rho$ \\
\hline \multicolumn{3}{|c|}{ Spring 1999 - Male } \\
\hline GSI & PAHsum & $-0.3927 *$ \\
\hline GSI & PCBsum & $-0.3248^{*}$ \\
\hline GSI & Cadmium & $-0.3267^{*}$ \\
\hline \multicolumn{3}{|c|}{ Spring 2000 - Male } \\
\hline GSI & PAHsum & 0.1734 \\
\hline GSI & PCBsum & -0.1215 \\
\hline \multicolumn{3}{|c|}{ Spring 1999 - Female } \\
\hline GSI & PAHsum & $-0.4147^{*}$ \\
\hline GSI & PCBsum & -0.1631 \\
\hline Vtg & PAHsum & $-0.5095^{*}$ \\
\hline Vtg & PCBsum & -0.227 \\
\hline \multicolumn{3}{|c|}{ Spring 2000 - Female } \\
\hline GSI & PAHsum & $-0.4454^{*}$ \\
\hline GSI & PCBsum & 0.0423 \\
\hline Vtg & PAHsum & $-0.3267^{*}$ \\
\hline Vtg & PCBsum & 0.123 \\
\hline
\end{tabular}

*Correlation was significantly different $(\alpha=0.05)$.

Values generated by running nonparametric correlations between reported contaminant levels versus the GSI and Vtg. PAHsum includes 12 polycyclic aromatic hydrocarbons; PCBsum, 5 polychlorinated biphenyls. 
Table 3. Comparis on of $F$. heteroclitus sex ratios at the sampling sites.

\begin{tabular}{lrrr}
\hline Site & Collection & $n$ & Chi Square \\
\hline Annapolis & Fall 1999 & 645 & $6.316^{*}$ \\
Annapolis & Spring 1999 & 217 & $40.974^{*}$ \\
Annapolis & Spring 2000 & 548 & $29.843^{*}$ \\
Back River & Fall 1998, 1999 & 470 & $4.110^{*}$ \\
Back River & Spring 1999 & 107 & 3.223 \\
Back River & Spring 2000 & 42 & 1.757 \\
Beaverdam Creek & Fall 1999 & 236 & 0.034 \\
Beaverdam Creek & Spring 1999, 2000 & 453 & 0.535 \\
Choptank River & Fall 1998, 1999 & 308 & 0.526 \\
Choptank River & Spring 1999, 2000 & 468 & 0.107 \\
Fort Armistead & Fall 1998, 1999 & 420 & 3.753 \\
Fort Armistead & Spring 1999 & 379 & $6.916^{*}$ \\
Fort Armistead & Spring 2000 & 183 & 0.011 \\
Patapsco River & Fall 1998, 1999 & 504 & 0.063 \\
Patapsco River & Spring 1999, 2000 & 366 & 0.137 \\
Point Lookout & Fall 1998, Spring 2000 & 778 & $13.462^{*}$ \\
\hline
\end{tabular}

* Significantly different $(\alpha=0.05)$ from 50:50 ratio of males to females.

Years within a season were combined when tests revealed no significant difference. 